\title{
Leucobacter tardus sp. nov., isolated from the phyllosphere of Solanum tuberosum L.
}

Correspondence Undine Behrendt ubehrendt@zalf.de

\section{Undine Behrendt, ${ }^{1}$ Andreas Ulrich ${ }^{1}$ and Peter Schumann ${ }^{2}$}

\author{
${ }^{1}$ Leibniz-Centre for Agricultural Landscape Research (ZALF), Institute of Landscape Matter \\ Dynamics, Eberswalder Str. 84, D-15374 Müncheberg, Germany \\ ${ }^{2}$ DSMZ - German Collection of Microorganisms and Cell Cultures, Inhoffenstr. 7B, D-38124 \\ Braunschweig, Germany
}

\begin{abstract}
In the course of studying the composition of the microbial community in the phyllosphere of potato plants, a Gram-positive bacterium, strain $\mathrm{K} 70 / 01^{\top}$, was isolated. On the basis of $16 \mathrm{~S}$ rRNA gene sequence analysis, it was shown that the investigated isolate represents a novel species in the genus Leucobacter; the closest phylogenetic neighbour was Leucobacter chromiireducens subsp. chromiireducens, with a sequence similarity of $96.8 \%$ to the type strain. Chemotaxonomic characteristics supported affiliation to the genus Leucobacter. Strain $\mathrm{K} 70 / 01^{\top}$ displayed the diagnostic diamino acid 2,4-diaminobutyric acid in the cell-wall peptidoglycan. The major fatty acids were anteiso- $C_{15: 0}$, anteiso- $C_{17: 0}$ and iso- $C_{16: 0}$, which are typical of the genus. The quinone system consisted of the menaquinones MK-10, MK-11 and MK-9. Differences in several physiological features and the absence of the cell-wall amino acids $\gamma$-aminobutyric acid and threonine enabled the isolate to be differentiated from all recognized Leucobacter species. Based on these phylogenetic and phenotypic results, it can be concluded that the isolate from the phyllosphere of potato plants represents a novel species, for which the name Leucobacter tardus sp. nov. is proposed. The type strain is $\mathrm{K} 70 / 01^{\top}\left(=\mathrm{DSM} 19811^{\top}=\mathrm{LMG} 24388^{\top}\right)$.
\end{abstract}

The genus Leucobacter was proposed by Takeuchi et al. (1996) to accommodate a species representing a distinct phylogenetic lineage in the family Microbacteriaceae that was characterized by the presence of $\gamma$-aminobutyric acid (GABA), an unusual amino acid, in the cell wall. The number of members of the genus Leucobacter has increased recently through the description of several novel species (Lin et al., 2004; Morais et al., 2004, 2006; Muir \& Tan, 2007; Somvanshi et al., 2007). Although all species are characterized by the diagnostic diamino acid 2,4-diaminobutyric acid (DAB) in the peptidoglycan, the cell-wall type of the genus is not consistent, as differences in the amino acid composition have been detected in several species. The unusual GABA has been found only in Leucobacter albus and Leucobacter komagatae. Nevertheless, phylogenetic studies on the basis of $16 \mathrm{~S}$ rRNA gene sequences have shown that the species of the genus form a monophyletic assemblage.

Strains belonging to this genus have been recovered from diverse ecological niches, such as activated sludge from chromium-contaminated wastewater (Morais et al., 2004, 2006), soil (Lin et al., 2004), river sediments (Morais et al.,

Abbreviation: DAB, 2,4-diaminobutyric acid; GABA, $\gamma$-aminobutyric acid. The GenBank/EMBL/DDBJ accession number for the 16S rRNA gene sequence of strain $\mathrm{K} 70 / 01^{\top}\left(=\mathrm{DSM} 19811^{\top}=\mathrm{LMG} 24388^{\top}\right)$ is AM940158.
2006), the water phase of tropospheric clouds (Amato et al., 2007) and nematodes (Muir \& Tan, 2007; Somvanshi et al., 2007). In the course of studying the composition of microbial communities in the phyllosphere of potato plants, a strain was isolated that was tentatively affiliated to the genus Leucobacter by partial $16 \mathrm{~S}$ rRNA gene sequence comparison. As a consequence, an extensive phenotypic and phylogenetic investigation was performed to reveal the unambiguous taxonomic position of this phyllosphere isolate.

To study the bacterial community composition, samples from the pinnate leaves of potato plants were processed as described by Heuer \& Smalla (1999). Culturable bacteria were investigated on various media after incubation at $21{ }^{\circ} \mathrm{C}$ for 7 days. The strain under study, $\mathrm{K} 70 / 01^{\mathrm{T}}$, was isolated from Baird-Parker agar (Oxoid), used as a semiselective medium particularly to favour the isolation of bacteria of the family Micrococcaceae.

Phylogenetic analysis of strain $\mathrm{K} 70 / 01^{\mathrm{T}}$ on the basis of $16 \mathrm{~S}$ rRNA gene sequences was performed as described by Behrendt et al. (2003). Phylogenetic trees were based on a 1445 nt alignment (Escherichia coli positions 38-1469) and constructed using the neighbour-joining (Saitou \& Nei, 1987) and maximum-likelihood (Felsenstein, 1981) algorithms (PHYLIP version 3.6; Felsenstein, 1993). As shown in Fig. 1, the isolate clustered clearly with Leucobacter species 


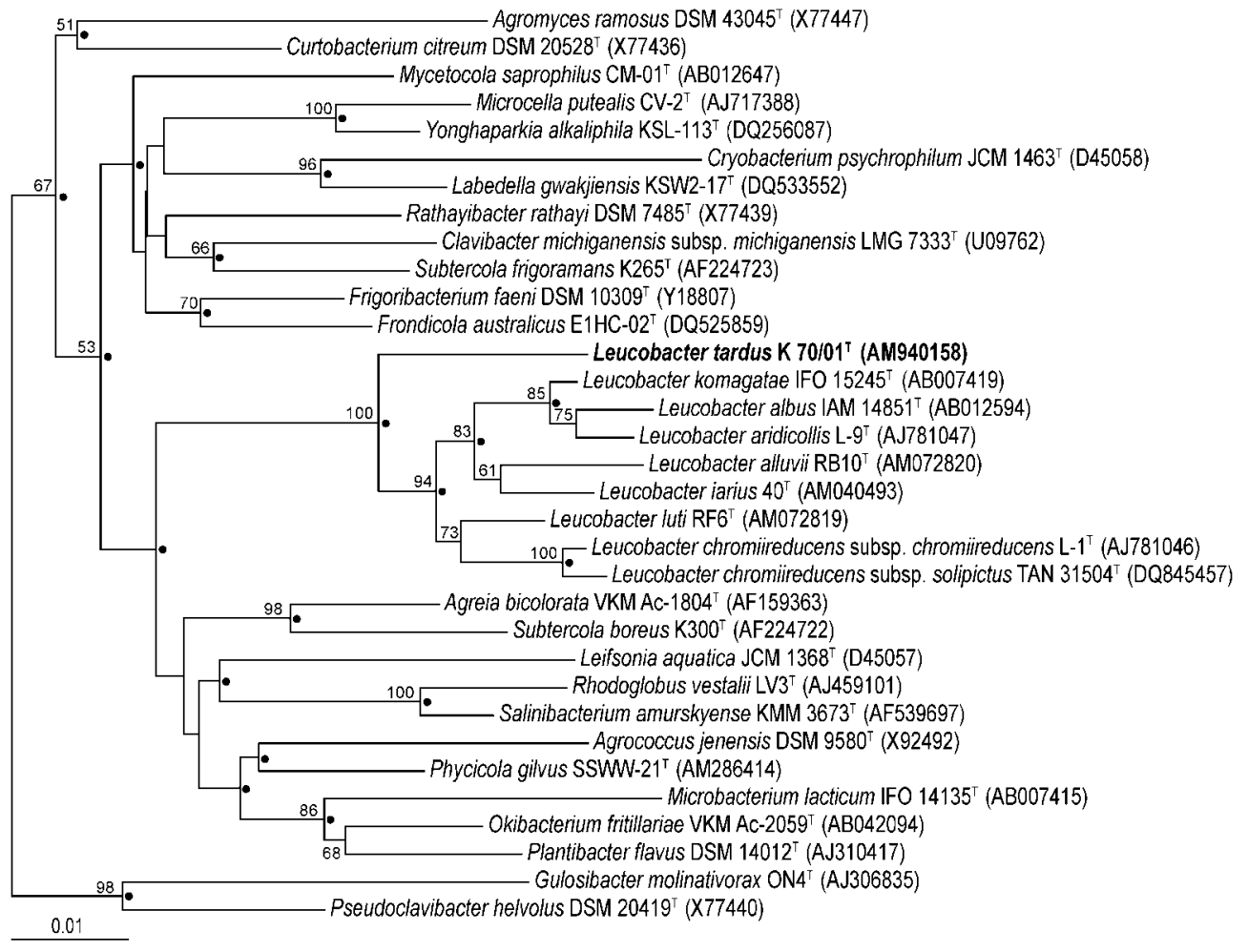

Fig. 1. Neighbour-joining tree based on nearly complete $16 \mathrm{~S}$ rRNA gene sequences showing the relationship between strain $\mathrm{K} 70 / 01^{\top}$, established species of the genus Leucobacter and type strains from all genera of the family Microbacteriaceae. Dots indicate branches of the tree that were also formed by using the maximum-likelihood method (Felsenstein, 1981). The sequence of Arthrobacter globiformis DSM $20124^{\top}$ (GenBank accession no. M23411) was used as an outgroup (not shown). Numbers at nodes indicate levels of bootstrap support $>50 \%$ based on 1000 resampled datasets. Bar, 0.01 changes per nucleotide position.

using both treeing methods. This branch was supported by a $100 \%$ bootstrap confidence level. Nevertheless, strain $\mathrm{K} 70 / 01^{\mathrm{T}}$ was separate from the other Leucobacter species within this branch, reflecting the higher sequence similarities among almost all of the established species in comparison with the novel isolate. Pairwise comparisons of 16S rRNA gene sequences between the investigated isolate and the type strains of Leucobacter species revealed similarity values in the range $95.8-96.8 \%$; the shortest evolutionary distance was from Leucobacter chromiireducens subsp. chromiireducens. The sequence divergence value of $>3 \%$ for the phyllosphere isolate was higher than the recommended threshold value that is accepted as a criterion for the delineation of different species (Stackebrandt \& Goebel, 1994; Stackebrandt et al., 2002). Strain $\mathrm{K} 70 / 01^{\mathrm{T}}$ can thus be considered to be a representative of a separate species in the genus Leucobacter on the basis of phylogenetic analysis.

In the family Microbacteriaceae, several chemotaxonomic features are important for genus identification and species affiliation (Evtushenko \& Takeuchi, 2006). The composition of the cell-wall peptidoglycan in particular is a prominent feature for characterizing novel species. The amino acids and peptides in cell-wall peptidoglycan hydrolysates were analysed by two-dimensional ascending TLC on cellulose plates using the solvent system described by Schleifer \& Kandler (1972). The peptidoglycan of strain $\mathrm{K} 70 / 01^{\mathrm{T}}$ consisted of the amino acids alanine, glycine, $\mathrm{DAB}$ and glutamic acid (molar ratio $3.2: 2.1: 0.5: 1.0$ ). This composition was most similar to that determined for Leucobacter aridicollis (Morais et al., 2004). As with $L$. aridicollis, no GABA or threonine was found in the isolate, whereas all other members of the genus have either GABA or threonine in their peptidoglycan (Table 1). Nevertheless, the presence of the diagnostic diamino acid $\mathrm{DAB}$ in the isolated strain corresponds with the description of members of the genus Leucobacter (Takeuchi et al., 1996). A further chemotaxonomic feature, the isoprenoid quinone composition, was determined as described by Groth et al. (1996). The quinone system of strain K 70/01 ${ }^{\mathrm{T}}$ consisted of the menaquinones MK-10, MK-11 and MK-9 (molar ratio 9:7:1). As shown in Table 1, menaquinones of the established Leucobacter species are dominated by MK-11, whereas MK-10 and MK-11 were the predominant menaquinones in the investigated strain. Thus, strain $\mathrm{K} 70 / 01^{\mathrm{T}}$ can be differentiated from other species of the genus by this chemotaxonomic feature. The cellular fatty acid composition of cells grown on tryptic soy agar (TSA; Merck) for $24 \mathrm{~h}$ at $28{ }^{\circ} \mathrm{C}$ was determined with the Sherlock 
Table 1. Differential phenotypic characteristics of Leucobacter species

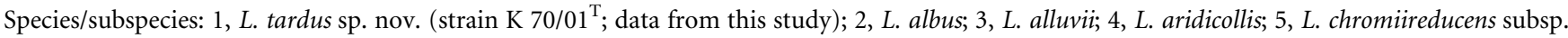
chromiireducens; 6, L. chromiireducens subsp. solipictus; 7, L. iarius; 8, L. komagatae; 9, L. luti. Except where indicated, data for reference taxa were taken from Takeuchi et al. (1996), Lin et al. (2004), Morais et al. (2004, 2006), Muir \& Tan (2007) and Somvanshi et al. (2007). +, Positive; -, negative; w, weak reaction; $+/-$, different reactions obtained; ND, no data available.

\begin{tabular}{|c|c|c|c|c|c|c|c|c|c|}
\hline Characteristic & 1 & 2 & 3 & 4 & 5 & 6 & 7 & 8 & 9 \\
\hline \multicolumn{10}{|c|}{ Cell-wall amino acids (molar ratios) } \\
\hline DAB & 0.5 & 0.8 & 0.5 & 1.0 & 1.0 & 0.5 & 0.5 & 0.8 & 1.0 \\
\hline Alanine & 3.2 & 1.8 & 2.4 & 4.0 & 2.1 & 1.8 & 1.5 & 1.9 & 1.0 \\
\hline Glycine & 2.1 & 1.1 & 1.2 & 2.3 & 1.4 & 1.0 & 0.9 & 0.9 & 0.6 \\
\hline Glutamic acid & 1.0 & 1.0 & 1.0 & 2.0 & 1.1 & 1.0 & 1.0 & 1.0 & 2.0 \\
\hline GABA & - & 0.7 & - & - & - & - & - & 0.7 & - \\
\hline Threonine & - & - & 0.7 & - & 0.7 & 0.6 & 0.7 & - & 0.6 \\
\hline \multicolumn{10}{|l|}{ Menaquinones (MK) } \\
\hline Major components & 10,11 & 11 & 11 & 11 & 11 & 11 & 11 & 11 & 11 \\
\hline Minor components & 9 & 12,9 & 10 & 10 & 10 & 10 & $10,9,12^{*}$ & 10,12 & 10 \\
\hline \multicolumn{10}{|c|}{ Utilization of (in Biolog GP2 MicroPlates): $\dagger$} \\
\hline$N$-Acetyl-D-glucosamine & - & - & - & - & - & - & + & - & - \\
\hline N-Acetyl-L-glutamic acid & + & + & - & - & - & - & - & - & $\mathrm{w}$ \\
\hline Adenosine & + & $\mathrm{w}$ & + & + & + & - & + & - & - \\
\hline AMP & - & - & - & + & - & - & $\mathrm{w}$ & - & - \\
\hline L-Alaninamide & + & + & + & + & + & + & + & + & - \\
\hline L-Alanine & - & $\mathrm{w}$ & + & + & + & + & $\mathrm{w}$ & - & + \\
\hline L-Alanyl glycine & - & + & + & + & $+1-$ & + & - & - & - \\
\hline L-Arabinose & + & - & - & - & - & - & - & - & - \\
\hline L-Asparagine & - & + & - & + & - & - & - & - & - \\
\hline 2,3-Butanediol & + & - & - & - & - & - & - & - & - \\
\hline $2^{\prime}$-Deoxyadenosine & + & + & - & + & + & - & - & + & $\mathrm{w}$ \\
\hline Dextrin & - & - & + & - & - & - & - & - & - \\
\hline D-Fructose & $\mathrm{w}$ & - & + & - & - & - & + & - & - \\
\hline D-Fructose 6-phosphate & - & + & + & + & $+1-$ & - & + & + & + \\
\hline D-Gluconic acid & + & - & - & - & - & - & - & - & - \\
\hline$\alpha$-D-Glucose & + & - & + & - & - & - & - & - & - \\
\hline D-Glucose 6-phosphate & + & - & - & - & - & - & - & - & - \\
\hline L-Glutamic acid & - & + & - & + & + & + & $\mathrm{w}$ & $\mathrm{w}$ & $\mathrm{w}$ \\
\hline Glycerol & + & + & + & + & - & + & + & + & - \\
\hline DL- $\alpha$-Glycerol phosphate & + & - & - & - & - & - & - & - & - \\
\hline Glycyl L-glutamic acid & - & + & - & + & + & + & + & w & $\mathrm{w}$ \\
\hline$\alpha$-Hydroxybutyric acid & + & - & - & - & - & - & - & - & - \\
\hline$\beta$-Hydroxybutyric acid & - & - & - & + & - & - & - & - & - \\
\hline$p$-Hydroxyphenylacetic acid & + & - & + & + & + & + & + & $\mathrm{w}$ & + \\
\hline$\alpha$-Ketovaleric acid & $\mathrm{w}$ & + & - & $\mathrm{w}$ & - & - & - & - & - \\
\hline L-Lactic acid & + & - & + & - & - & - & - & - & - \\
\hline Methyl $\alpha$-D-galactoside & + & - & - & - & - & - & - & - & - \\
\hline Methyl $\beta$-D-galactoside & + & - & - & - & - & $\mathrm{ND}$ & - & - & - \\
\hline 3-Methyl glucose & + & - & - & - & - & - & - & - & - \\
\hline Methyl pyruvate & + & + & + & - & + & $\mathrm{w}$ & - & - & + \\
\hline Putrescine & + & - & - & - & $+1-$ & + & - & - & - \\
\hline Pyruvic acid & + & - & - & - & - & - & - & - & - \\
\hline D-Ribose & + & + & - & + & - & - & + & + & - \\
\hline L-Serine & + & + & - & + & $+1-$ & + & $\mathrm{w}$ & - & - \\
\hline D-Sorbitol & + & - & - & - & - & - & - & - & - \\
\hline Succinamic acid & + & - & - & - & - & $\mathrm{w}$ & - & - & - \\
\hline Succinic acid & + & - & - & - & - & - & - & - & - \\
\hline
\end{tabular}


Table 1. cont.

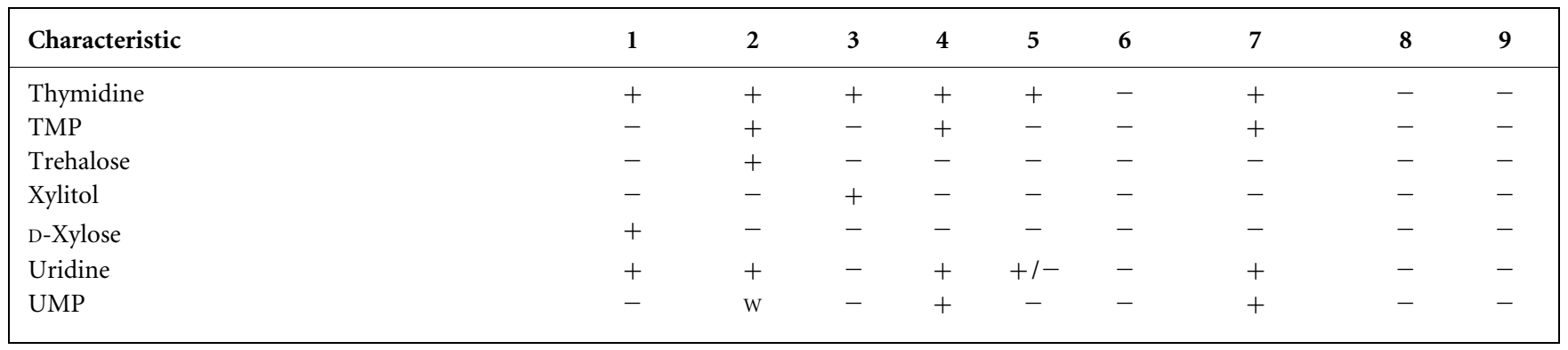

${ }^{\star}$ Trace amounts.

$\dagger$ Apart from strain K 70/01 ${ }^{\mathrm{T}}$, data are from Muir \& Tan (2007) and Somvanshi et al. (2007).

Microbial Identification system (MIDI version 4.5) as described by Behrendt et al. (1999). The fatty acid profile of strain $\mathrm{K} 70 / 01^{\mathrm{T}}$ consisted of the branched fatty acids anteiso$\mathrm{C}_{15: 0}(53.0 \%)$, anteiso- $\mathrm{C}_{17: 0}(25.8 \%)$, iso- $\mathrm{C}_{16: 0}(14.3 \%)$, iso- $\mathrm{C}_{15: 0}(1.5 \%)$ and iso- $\mathrm{C}_{14: 0}(1.1 \%)$ and the straightchain fatty acid $\mathrm{C}_{16: 0}(3.0 \%)$. Furthermore, traces $(<1.0 \%$ of total fatty acids) of the branched fatty acids iso- $\mathrm{C}_{17: 0}$ and anteiso- $\mathrm{C}_{13: 0}$, the unsaturated fatty acid anteiso- $\mathrm{C}_{15: 1}$ and the straight-chain fatty acids $\mathrm{C}_{14: 0}$ and $\mathrm{C}_{15: 0}$ were found. This fatty acid profile is similar to those of other Leucobacter species. The presence of large amounts of anteiso- $\mathrm{C}_{15: 0}$, anteiso- $\mathrm{C}_{17: 0}$ and iso- $\mathrm{C}_{16: 0}$ is typical of members of the genus (Muir \& Tan, 2007; Somvanshi et al., 2007).

Morphological and physiological characterization of the phyllosphere isolate was performed as described by Behrendt et al. (1999). Unless stated otherwise, the strain was cultivated on nutrient agar (Sifin) or in the respective broth at $21{ }^{\circ} \mathrm{C}$. The optimal growth temperature was determined by turbidity measurements at $10,15,21,25,30$ and $35^{\circ} \mathrm{C}$ after $24 \mathrm{~h}$ incubation in liquid medium. Growth at 4 and $37{ }^{\circ} \mathrm{C}$ was tested on agar plates after 7 days of incubation. Aerobic acid production from carbohydrates was assessed using an API 50CH strip inoculated with a bacterial suspension (from a $24 \mathrm{~h}$-old culture grown at $25{ }^{\circ} \mathrm{C}$ on TSA) in $\mathrm{CHB} / \mathrm{E}$ medium (bioMérieux). Results were determined for up to 5 days incubation at $30{ }^{\circ} \mathrm{C}$ as indicated by Morais et al. (2004) and Somvanshi et al. (2007). Additional physiological and enzymic characteristics were determined using the API 20E test strip (bioMérieux) according to the manufacturer's instructions. Acid production from carbohydrates was tested under aerobic conditions. An extensive investigation of carbon substrate utilization was conducted using Biolog GP2 MicroPlates (MicroLog System) as recommended by the manufacturer. Results were scored visually after 24 and $48 \mathrm{~h}$ incubation at $30{ }^{\circ} \mathrm{C}$. Detailed characteristics of strain $\mathrm{K} 70 / 01^{\mathrm{T}}$ are given in the species description. The investigated strain reacted negatively towards most of the substrates provided on the API $50 \mathrm{CH}$ test strips, which was similar to the results for Leucobacter species obtained by Somvanshi et al. (2007). Only a few carbohydrates could be assimilated following prolonged incubation. Similar results were obtained for reactions on the API 20E substrates. In contrast, several carbohydrates provided on the Biolog GP2 MicroPlates were utilized within $48 \mathrm{~h}$. This result supported the observation by Somvanshi et al. (2007) that GP2 test plates are more suitable for distinguishing Leucobacter species than the other methods used. As shown in Table 1, the investigated strain differed from other Leucobacter species in its utilization of a number of carbohydrates. Thus, the substrate utilization pattern on GP2 MicroPlates was an effective feature for distinguishing strain $\mathrm{K} 70 / 01^{\mathrm{T}}$ from other species of the genus Leucobacter.

As a result of the phylogenetic and phenotypic analyses, it was clearly demonstrated that strain $\mathrm{K} 70 / 01^{\mathrm{T}}$, isolated from the phyllosphere of potato plants, represents a novel species of the genus Leucobacter, for which the name Leucobacter tardus sp. nov. is proposed.

\section{Description of Leucobacter tardus sp. nov.}

Leucobacter tardus (tar'dus. L. masc. adj. tardus slow, pertaining to the slow reactions in several physiological tests).

Cells are asporogenous, non-motile, short rods (0.4$0.6 \times 0.8-1.6 \mu \mathrm{m}$ ), which occur singly or in pairs, sometimes forming small irregular clusters. Gram-positive and strictly aerobic. The lemon-yellow colonies found on nutrient agar are smooth with regular margins. Optimal temperature for growth is $21-30{ }^{\circ} \mathrm{C}$; no growth at 4 or $37{ }^{\circ} \mathrm{C}$. Catalase activity is present, but urease, $\beta$-galactosidase, arginine dihydrolase, lysine decarboxylase and ornithine decarboxylase activities are absent. Citrate utilization, $\mathrm{H}_{2} \mathrm{~S}$ production from sodium thiosulfate, tryptophan deaminase, indole production from L-tryptophan and reduction of nitrate are negative. Does not produce acetoin from sodium pyruvate. No growth on MacConkey agar. Weak oxidase reaction. Hydrolyses aesculin, but not starch, casein or gelatin. Oxidative acid production occurs on API $50 \mathrm{CH}$ and API 20E substrates for D-fructose, melezitose, raffinose and L-rhamnose, but not for $\mathrm{N}$-acetylglucosamine, D-adonitol, amygdalin, D- or L-arabinose, D- or L-arabitol, arbutin, D-cellobiose, dulcitol, erythritol, D- or L-fucose, D-galactose, gentiobiose, Dglucose, glycerol, glycogen, inositol, inulin, D-lactose, D- 
lyxose, maltose, D-mannitol, D-mannose, melibiose, methyl $\alpha$-D-glucopyranoside, methyl $\alpha$-D-mannopyranoside, methyl $\beta$-D-xylopyranoside, potassium gluconate, potassium 2-ketogluconate, potassium 5-ketogluconate, Dribose, sucrose, salicin, D-sorbitol, L-sorbose, starch, Dtagatose, trehalose, turanose, xylitol or D- or L-xylose. Utilizes $\mathrm{N}$-acetyl-L-glutamic acid, adenosine, L-alaninamide, L-arabinose, 2,3-butanediol, 2'-deoxyadenosine, Dgluconic acid, $\alpha$-D-glucose, D-glucose 6-phosphate, glycerol, DL- $\alpha$-glycerol phosphate, $\alpha$-hydroxybutyric acid, $p$ hydroxyphenylacetic acid, L-lactic acid, methyl $\alpha$-D-galactoside, methyl $\beta$-D-galactoside, 3-methyl glucose, methyl $\alpha$ D-glucoside, methyl pyruvate, putrescine, pyruvic acid, Dribose, L-serine, D-sorbitol, succinamic acid, succinic acid, thymidine, Tweens 40 and 80 , uridine and D-xylose on Biolog GP2 MicroPlates. Weak utilization is observed for D-fructose, myo-inositol, $\alpha$-ketovaleric acid, D-mannitol, palatinose, D-psicose and D-tagatose. Acetic acid, $\mathrm{N}$-acetylD-glucosamine, $N$-acetyl- $\beta$-D-mannosamine, AMP, D- and L-alanine, L-alanyl glycine, amygdalin, D-arabitol, arbutin, $\mathrm{L}$-asparagine, D-cellobiose, $\alpha$ - and $\beta$-cyclodextrin, dextrin, D-fructose 6-phosphate, L-fucose, D-galactose, D-galacturonic acid, gentiobiose, $\alpha$-D-glucose 1-phosphate, L-glutamic acid, glycogen, glycyl L-glutamic acid, $\beta$ - and $\gamma$-hydroxybutyric acids, inosine, inulin, $\alpha$-ketoglutaric acid, lactamide, D-lactic acid methyl ester, $\alpha$-D-lactose, lactulose, D- and L-malic acid, maltose, maltotriose, mannan, Dmannose, melezitose, melibiose, methyl $\beta$-D-glucoside, methyl $\alpha$-D-mannoside, monomethyl succinate, propionic acid, L-pyroglutamic acid, raffinose, L-rhamnose, salicin, sedoheptulosan, stachyose, sucrose, TMP, trehalose, turanose, UMP and xylitol are not assimilated. Cell-wall amino acids are DAB, alanine, glycine and glutamic acid. The main menaquinones are MK-10, MK-11 and MK-9. The fatty acid profile consists predominantly of anteiso-

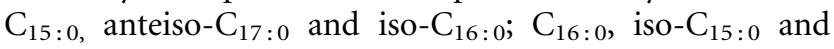
iso- $\mathrm{C}_{14: 0}$ are present in minor amounts.

The type strain is $\mathrm{K} 70 / 01^{\mathrm{T}}$ (=DSM $19811^{\mathrm{T}}=\mathrm{LMG}$ $24388^{\mathrm{T}}$ ), isolated from the phyllosphere of potato plants in Dahnsdorf (Germany).

\section{Acknowledgements}

This work was supported by grant 0312632D from the Federal Ministry of Education and Research. We wish to thank Mrs B. Selch, Mrs S. Weinert (ZALF-Müncheberg), Mrs G. Pötter and Mrs A. Wasner (DSMZ - Braunschweig) for their excellent technical assistance. Furthermore, we would like to acknowledge Professor Dr H. G. Trüper (Rheinische Friedrich-Wilhelm-Universität, Bonn) for his help with the Latin construction of the species name.

\section{References}

Amato, P., Parazols, M., Sancelme, M., Laj, P., Mailhot, G. \& Delort, A.-M. (2007). Microorganisms isolated from the water phase of tropospheric clouds at the Puy de Dôme: major groups and growth abilities at low temperatures. FEMS Microbiol Ecol 59, 242-254.
Behrendt, U., Ulrich, A., Schumann, P., Erler, W., Burghardt, J. \& Seyfarth, W. (1999). A taxonomic study of bacteria isolated from grasses: a proposed new species Pseudomonas graminis sp. nov. Int $J$ Syst Bacteriol 49, 297-308.

Behrendt, U., Ulrich, A. \& Schumann, P. (2003). Fluorescent pseudomonads associated with the phyllosphere of grasses; Pseudomonas trivialis sp. nov., Pseudomonas poae sp. nov. and Pseudomonas congelans sp. nov. Int J Syst Evol Microbiol 53, 1461-1469.

Evtushenko, L. I. \& Takeuchi, M. (2006). The family Microbacteriaceae. In The Prokaryotes. A Handbook on the Biology of Bacteria, 3rd edn, vol. 3, pp. 1020-1098. Edited by M. Dworkin, S. Falkow, E. Rosenberg, K.-H. Schleifer \& E. Stackebrandt. New York: Springer.

Felsenstein, J. (1981). Evolutionary trees from DNA sequences: a maximum likelihood approach. J Mol Evol 17, 368-376.

Felsenstein, J. (1993). PHYLIP (phylogeny inference package), version 3.5c. Distributed by the author. Department of Genome Sciences, University of Washington, Seattle, USA.

Groth, I., Schumann, P., Weiss, N., Martin, K. \& Rainey, F. A. (1996). Agrococcus jenensis gen. nov., sp. nov., a new genus of actinomycetes with diaminobutyric acid in the cell wall. Int J Syst Bacteriol 46, 234-239.

Heuer, H. \& Smalla, K. (1999). Bacterial phyllosphere communities of Solanum tuberosum L. and T4-lysozyme-producing transgenic variants. FEMS Microbiol Ecol 28, 357-371.

Lin, Y.-C., Uemori, K., de Briel, D. A., Arunpairojana, V. \& Yokota, A. (2004). Zimmermannella helvola gen. nov., sp. nov., Zimmermannella alba sp. nov., Zimmermannella bifida sp. nov., Zimmermannella faecalis sp. nov. and Leucobacter albus sp. nov., novel members of the family Microbacteriaceae. Int J Syst Evol Microbiol 54, 1669-1676.

Morais, P. V., Francisco, R., Branco, R., Chung, A. P. \& da Costa, M. S. (2004). Leucobacter chromiireducens sp. nov, and Leucobacter aridicollis sp. nov., two new species isolated from a chromium contaminated environment. Syst Appl Microbiol 27, 646-652.

Morais, P. V., Paulo, C., Francisco, R., Branco, R., Chung, A. P. \& da Costa, M. S. (2006). Leucobacter luti sp. nov., and Leucobacter alluvii sp. nov., two new species of the genus Leucobacter isolated under chromium stress. Syst Appl Microbiol 29, 414-421.

Muir, R. E. \& Tan, M.-W. (2007). Leucobacter chromiireducens subsp. solipictus subsp. nov., a pigmented bacterium isolated from the nematode Caenorhabditis elegans, and emended description of $L$. chromiireducens. Int J Syst Evol Microbiol 57, 2770-2776.

Saitou, N. \& Nei, M. (1987). The neighbor-joining method: a new method for reconstructing phylogenetic trees. Mol Biol Evol 4, 406-425.

Schleifer, K. H. \& Kandler, O. (1972). Peptidoglycan types of bacterial cell walls and their taxonomic implications. Bacteriol Rev 36, 407-477.

Somvanshi, V. S., Lang, E., Schumann, P., Pukall, R., Kroppenstedt, R. M., Ganguly, S. \& Stackebrandt, E. (2007). Leucobacter iarius sp. nov., in the family Microbacteriaceae. Int J Syst Evol Microbiol 57, 682-686.

Stackebrandt, E. \& Goebel, B. M. (1994). Taxonomic note: a place for DNA-DNA reassociation and $16 \mathrm{~S}$ rRNA sequence analysis in the present species definition in bacteriology. Int J Syst Bacteriol 44, 846-849.

Stackebrandt, E., Frederiksen, W., Garrity, G. M., Grimont, P. A. D., Kämpfer, P., Maiden, M. C. J., Nesme, X., Rosselló-Mora, R., Swings, J. \& other authors (2002). Report of the ad hoc committee for the reevaluation of the species definition in bacteriology. Int J Syst Evol Microbiol 52, 1043-1047.

Takeuchi, M., Weiss, N., Schumann, P. \& Yokota, A. (1996). Leucobacter komagatae gen. nov., sp. nov., a new aerobic Grampositive, nonsporulating rod with 2,4-diaminobutyric acid in the cell wall. Int J Syst Bacteriol 46, 967-971. 